University of Nebraska - Lincoln

DigitalCommons@University of Nebraska - Lincoln

Papers in Plant Pathology

Plant Pathology Department

January 2007

\title{
Genetic analysis of a novel Alaska barley yellow dwarf virus in the family Luteoviridae
}

N.L. Robertson

United States Department of Agriculture, Agricultural Research Service

Roy C. French

University of Nebraska-Lincoln, rfrench2@unl.edu

Follow this and additional works at: https://digitalcommons.unl.edu/plantpathpapers

Part of the Plant Pathology Commons

Robertson, N.L. and French, Roy C., "Genetic analysis of a novel Alaska barley yellow dwarf virus in the family Luteoviridae" (2007). Papers in Plant Pathology. 8.

https://digitalcommons.unl.edu/plantpathpapers/8

This Article is brought to you for free and open access by the Plant Pathology Department at DigitalCommons@University of Nebraska - Lincoln. It has been accepted for inclusion in Papers in Plant Pathology by an authorized administrator of DigitalCommons@University of Nebraska - Lincoln. 
Arch Virol (2007) 152: 369-382

DOI 10.1007/s00705-006-0846-4

Printed in The Netherlands
Archives of Virology

\title{
Genetic analysis of a novel Alaska barley yellow dwarf virus in the family Luteoviridae
}

\author{
N. L. Robertson ${ }^{1}$ and R. French ${ }^{2}$ \\ ${ }^{1}$ United States Department of Agriculture, Agricultural Research Service, Subarctic \\ Agricultural Research Unit, Arctic Germplasm Introduction and Research Project, \\ University of Alaska-Fairbanks, Palmer Research Station, Palmer, AK, U.S.A. \\ ${ }^{2}$ United States Department of Agriculture, Agricultural Research Service, \\ University of Nebraska-Lincoln, Lincoln, NE, U.S.A.
}

Received March 29, 2006; accepted August 7, 2006

Published online October 2, 2006 (C) Springer-Verlag 2006

Summary. A new plant virus belonging to the family Luteoviridae and isolated from diseased oat (Avena sativa L.) plants was discovered in Alaska in 2003. Even though plants with red/orange leaves were indicative of barley yellow dwarf disease, they were not reactive to specific antibodies corresponding to barley yellow dwarf virus (BYDV)-MAV, -PAV, -SGV, and cereal yellow dwarf virus-RPV from enzyme-linked immunosorbent assays (ELISA). An alternative RT-PCR assay that incorporated Shu-F/Yan-R primers for detection of BYDV-MAV, -PAS, -PAV, and SGV was effective in producing $~ 830$-nt fragments that contained genomic sequences to the $3^{\prime}$-terminus of the polymerase gene (ORF 2), the intergenic region $(\sim 113 \mathrm{nt})$, the coat protein gene (ORF 3$)$, and the putative movement gene (ORF 4). The Alaskan isolates were most similar to BYDV-MAV with only about 77 and $80 \%$ amino acid identity in the CP and ORF 4, respectively. The Alaska isolates coat protein gene sequences differed in several regions that otherwise are conserved among BYDV-MAV isolates, and may be important in serological variations, accounting for the negative ELISA results. Based upon sequence and serological differences, we concluded that the Alaskan BYDV-MAV-like isolates formed a novel species tentatively in the genus Luteovirus, and propose the name BYDV-ORV (oat red-leaf virus).

\section{Introduction}

Barley yellow dwarf (BYD) disease exclusively afflicts plant species in the grass family, Poaceae, and is especially noticeable wherever crops such as barley, maize,

Nucleotide sequence data reported are available in the DDBJ/EMBL/GenBank databases under the accessions numbers DQ680114-DQ680140, DQ683252, DQ792506. 
oats, rye, rice, and wheat are cultivated [3]. At least eight viruses belonging to the family Luteoviridae cause BYD, and are directly responsible as separate or multiple entities for economic losses incurred in the cereals and important range grasses [16]. Diseased plants may exhibit prominent yellow/red discolorations on leaves, extreme plant stunting, and reduced yield in grain. Most species were named, in part, after their most efficient aphid vector and taxonomically classified as: 1) genus Luteovirus: BYDV-MAV (Sitobion (Macrosiphum) avenae), BYDVPAS (formerly PAV-129; Rhopalosiphum padi), BYDV-PAV (R.padi \& S. avenae), and BYDV-RGV (rice giallume), 2) genus Polerovirus: Cereal yellow dwarf virusRPV (formerly BYDV-RPV; R. padi), and 3) unassigned genera: BYDV-GPV (Schizaphis graminum \& R. padi), BYDV-RMV (R. maidis), and BYDV-SGV (S. graminum) [4, 19]. The species are distinguished by gene arrangement and sizes on a single-stranded RNA genome with $5.3-5.8 \mathrm{~kb}[4,19]$. The $5^{\prime}$-half consists of two major overlapping genes involved in replication (ORF 1 and 2), is conserved within a genus, and shares features of the polymerase gene with either carmoviruses or sobemoviruses; CYDV has an extra ORF (0) at the $5^{\prime}$ end. In contrast, the $3^{\prime}$-half is the most conserved portion of the genome among genera, containing the "Luteoviridae block" that consists of ORF 4 situated within the major coat protein gene (ORF 3 ) that is fused to ORF 5, resulting in a read-through domain; BYDVs have an extra ORF (6) at the $3^{\prime}$ terminus [22].

Detection and identification of B/CYDVs have been based on serology (ELISA, enzyme-linked immunosorbent assay), aphid transmission studies, and, more recently, PCR (polymerase chain reaction) assays with genomic sequences [8]. Field surveys involving B/CYDVs in epidemiological studies, aphid vector assessments, and specific species identification usually employ ELISA to process large number of samples quickly and fairly accurately [6, 7]. Conflicting results and confusion may occur in the detection of variants and members of previously unidentified species such as BYDV-PAS $[2,22]$. Also, different "lots" of antiserum may vary in sensitivity and consistency. A relatively large number of samples can be processed using PCR assays that are more sensitive than serological assays, with little concern for "lot" differences, and provide fragment copies of the genome for definitive sequence determination. Over a decade and a half ago, a universal luteovirus primer set, Lu1/Lu4, that spanned most of the coat protein $(\mathrm{CP})$ gene, was successfully employed for detection of six members of the family Luteoviridae: BYDV-MAV, BYDV-PAV, BYDV-SGV, CYDV-RPV, PLRV (potato leafroll virus), and BWYV (beet western yellows virus) [25]. Recent field surveys of barley and oats in Alaska have confirmed the presence of BYDV-PAV and CYDV-RPV isolates using ELISA and RT-PCR [24]. Upon sequencing the PCR products, we determined that all the isolates from south central Alaska previously identified as BYDV-PAV by serology were in fact BYDV-PAS (unpublished, N. L. Robertson \& R. French). Incorporating RT-PCR assays with sequence documentation from our field surveys was essential for definitive identifications, and usually eliminated any conflicting ELISA results. However, in 2003, a field containing oat plants with classical BYD symptoms, and within several kilometers of other fields with B/CYDV-infected oat and barley 
plants, proved to be problematic and quite puzzling. Initial screening of fresh plant tissue by ELISA and RT-PCR for luteoviruses detection failed in all but one sample where sequence analysis of the RT-PCR product (CP gene, accession no. DQ683252) showed that it was BYDV-PAS.

The following year, Malmstrom and Shu [17] reported a multiplexed RT-PCR protocol for detection and separation of B/CYDVs using a number of newly designed primers. A particular primer set, Yan-R/Shu-F, proved to be quite effective in detecting a virus from the described oat samples that previously had escaped from PCR and serological detections. This paper describes the detection and identification of a novel member of the family Luteoviridae and its occurrence in south central Alaska. The molecular diversity of the unique isolates was examined and compared with other B/CYDV isolates occurring in Alaska and throughout the world.

\section{Materials and methods}

\section{Plant materials}

During an August 2003 disease survey in the Matanuska Valley near Palmer, Alaska, an estimated one percent of the plants in a field of oats (field (site) 5) at the head-stage contained symptoms similar to barley yellow dwarf disease. Affected plants usually had bright red/orange discoloration on the younger leaves including the flag leaf, while the older leaves were green. Two/three discolored leaves were detached from each of the randomly chosen 39 plants (plus green leaves from two healthy plants), placed into labeled plastic bags, and stored at $4{ }^{\circ} \mathrm{C}$ for processing. Leaves from individual plants were cut into small pieces, and aliquots of $0.1-0.25$ and $0.5 \mathrm{~g}$ were packaged and frozen at $-80^{\circ} \mathrm{C}$.

\section{ELISA}

Samples from each plant were screened for BYDV-MAV, BYDV-PAV, and BYDV-SGV utilizing DAS (double antibody sandwich)-ELISA and compound direct for CYDV-RPV with alkaline phosphatase enzyme conjugate from Agdia PathoScreen kits (Elkhart, IN) as directed from manufacturer. Briefly, $0.1-0.25 \mathrm{~g}$ leaf tissue was ground in $1.0 \mathrm{ml}$ distilled water with mortar and pestle, $10 \mu \mathrm{l}$ of the extract mixed with $90 \mu \mathrm{l}$ extraction buffer, applied to provided microtitre plates, and completed with positive and negative controls according to manufacturer directions. Further confirmation for BYDV-MAV was later tested from the same frozen leaf extracts using a DAS-ELISA kit from BIOREBA AG (Reinach, Switzerland) as instructed by the manufacturer. All assays were analyzed on a VERSAmax microplate reader (Molecular Devices, Sunnydale, CA, USA) at $405 \mathrm{~nm}$ with positive readings at least two times the negative control.

\section{Polymerase chain reaction, cloning, sequencing}

Total nucleic acid extracts from leaves of each of the 41 plants were processed as previously described [24] and stored at $-80^{\circ} \mathrm{C}$. Two to five micro liter nucleic acid and reverse primers, $\mathrm{Lu}$ 4 [25] or Yan-R [17] were used in the cDNA synthesis protocol as described by Robertson et al. [25]. The following PCR assays were performed using the same plant extracts with the following primer sets: 1) $\mathrm{Lu} \mathrm{1/Lu} \mathrm{4,} \mathrm{targeting} ~ 530 \mathrm{nt}$ on the CP gene (ORF 3) for all B/CYDVs, 2) Pol1/Lu 4, targeting $\sim 1400 \mathrm{nt}$ on the polymerase (ORF 2 ) and CP genes from only B/CYDVs that contain sobemovirus-like polymerases such as CYDV-RPV and BYDV-RMV [11] and, 
Table 1. Alaska barley yellow dwarf virus isolates detected from plants in 2003 from a field of oats by RT-PCR assays

\begin{tabular}{|c|c|c|c|c|c|}
\hline Plant no. ${ }^{a}$ & $\begin{array}{l}\text { RT-PCR } \\
\text { Lu1/Lu4 }{ }^{b}\end{array}$ & $\begin{array}{l}\text { RT-PCR } \\
\text { Shu-F/Yan-R }\end{array}$ & $\begin{array}{l}\text { RT-PCR } \\
\text { MAV2-F/Yan-R }\end{array}$ & Isolate $^{\mathrm{e}}$ & $\begin{array}{l}\text { Accession } \\
\text { number }^{\mathrm{f}}\end{array}$ \\
\hline 1 & - & + & - & & \\
\hline 2 & - & \pm & \pm & MAV02P5o03 & DQ680115 \\
\hline 3 & - & \pm & \pm & MAV03Р5o03 & DQ680116 \\
\hline 4 & - & \pm & \pm & MAV04P5o03 & DQ680131 \\
\hline 5 & - & - & $\mathrm{n} / \mathrm{a}$ & & \\
\hline 6 & - & - & $\mathrm{n} / \mathrm{a}$ & & \\
\hline 7 & - & \pm & \pm & MAV07P5o03 & DQ680114 \\
\hline 8 & - & \pm & - & MAV08P5o03 & DQ680117 \\
\hline 9 & - & \pm & $\mathrm{n} / \mathrm{a}$ & & \\
\hline 10 & - & - & $\mathrm{n} / \mathrm{a}$ & & \\
\hline 11 & $\mathrm{n} / \mathrm{a}$ & $\mathrm{n} / \mathrm{a}$ & $\mathrm{n} / \mathrm{a}$ & & \\
\hline 12 & - & \pm & - & MAV12P5o03 & DQ680118 \\
\hline 13 & - & \pm & - & MAV13P5o03 & DQ680119 \\
\hline 14 & - & \pm & \pm & MAV14P5o03 & DQ680120 \\
\hline 15 & - & \pm & \pm & MAV15P5o03 & DQ680121 \\
\hline 16 & - & \pm & \pm & MAV16P5o03 & DQ680122 \\
\hline 17 & - & \pm & \pm & MAV17P5o03 & DQ680132 \\
\hline 18 & - & - & $\mathrm{n} / \mathrm{a}$ & & \\
\hline 19 & - & \pm & - & MAV19P5o03 & DQ680123 \\
\hline 20 & - & + & - & & \\
\hline 21 & - & \pm & \pm & MAV21P5o03 & DQ680133 \\
\hline 22 & - & \pm & \pm & MAV22P5o03 & DQ680134 \\
\hline 23 & - & \pm & + & MAV23P5o03 & DQ680124 \\
\hline 24 & - & \pm & + & MAV24P5o03 & DQ680135 \\
\hline 25 & - & + & - & & \\
\hline 26 & - & \pm & \pm & MAV26P5o03 & DQ680138 \\
\hline 27 & - & \pm & \pm & MAV27P5o03 & DQ680126 \\
\hline 28 & - & \pm & - & MAV28P5o03 & DQ680127 \\
\hline 29 & - & \pm & - & MAV29P5o03 & DQ680128 \\
\hline 30 & - & \pm & \pm & MAV30P5o03 & DQ680129 \\
\hline 31 & - & - & $\mathrm{n} / \mathrm{a}$ & & \\
\hline 32 & - & - & $\mathrm{n} / \mathrm{a}$ & & \\
\hline 33 & - & - & $\mathrm{n} / \mathrm{a}$ & & \\
\hline 34 & - & - & $\mathrm{n} / \mathrm{a}$ & & \\
\hline 35 & - & - & $\mathrm{n} / \mathrm{a}$ & & \\
\hline 36 & - & - & $\mathrm{n} / \mathrm{a}$ & & \\
\hline \multirow[t]{2}{*}{37} & \pm & & - & PAS37P5o03_clone 1 & DQ683252 \\
\hline & & & & PAS37P5o03_clone 2 & DQ792506 \\
\hline 38 & - & \pm & \pm & MAV38P5o03 & DQ680136 \\
\hline 39 & - & \pm & \pm & MAV39P5o03 & DQ680130 \\
\hline 40 & - & - & $\mathrm{n} / \mathrm{a}$ & & \\
\hline 41 & - & - & $\mathrm{n} / \mathrm{a}$ & & \\
\hline \multirow[t]{2}{*}{ Total } & $1 / 41$ & $27 / 41$ & $16 / 27$ & 23 BYDV-MAV-like & \\
\hline & & & & 1 BYDV-PAS-like & \\
\hline
\end{tabular}

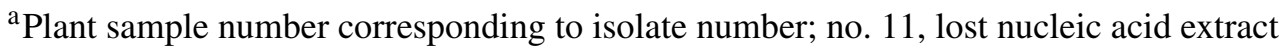
$+=$ obtained predicted size of fragment; $\pm=$ obtained sequences from fragment

${ }^{\mathrm{b}} \mathrm{PCR}$ product $\sim 530 \mathrm{bp}$

${ }^{\mathrm{c}} \mathrm{PCR}$ product $\sim 830 \mathrm{bp}$

${ }^{\mathrm{d}} \mathrm{PCR}$ product $\sim 590 \mathrm{bp}$

${ }^{\mathrm{e}} \mathrm{MAV}$ or PAS $=$ similar to BYDV-MAV or -PAS, XX (isolate number), $\mathrm{P}$ (Palmer $($ Alaska $)=$ location $), 5$ (field number), o (oat = natural plant host), 03 (year collected)

${ }^{\mathrm{f}}$ Nucleotide sequence obtained from central portion of PCR 830 fragment on both strands varying from 575 to $783 \mathrm{nts}$, except accession number DQ683252 (isolate PAS37P5o03_clone 1) is from central portion of PCR 530 fragment 
3) Shu-F/Yan-R, targeting $~ 830 \mathrm{nt}$ on the polymerase and the cp genes in BYDV-MAV, BYDV-PAV, or BYDV-SGV; PCR products of $\sim 830 \mathrm{bp}$ were further analyzed for specific BYDV-MAV, BYDV-PAV, and BYDV-SGV identification with MAV2-F/Yan-R, PAV-F/YanR, and Shu-F/SGV-R primers, respectively [17]. Modifications to the standard PCR protocol [25] for the reactions with species-specific primers included an increased amount of primers to $20-100 \mathrm{pmol}$, and an elevated annealing temperature $\left(55^{\circ} \mathrm{C}\right)$. Samples were placed in Gen Amp ${ }^{\circledR}$ PCR System 9700 (PE Applied Biosystems, Foster City, CA). The amplified DNA fragments were purified with QIAquick PCR Purification kit (QIAGEN Inc., Valencia, CA, USA), and visualized on ethidium-bromide-stained agarose gels for size and concentration determinations. The purified DNA samples and Shu-F, Yan-R, and MAV-F primers were submitted to Davis Sequencing, Inc. (Davis, CA) for direct sequencing of both DNA strands. The PCR fragment of $\sim 530$ bp derived from plant no. 37 with Lu1/Lu4 primers was cloned into pGem-T Easy (Promega, Madison, WI), transformed into Escherichia coli XL-2 Blue (Stratagene, La Jolla, CA), and sequenced on both strands. We were curious if BYDV-MAVlike isolates were present on other sites and, in addition to oats, if barley was also a host. Barley and oat plants from two different sites in 2003 and 2004 (within several kilometers of field 5) were specifically assayed for MAV detection using stored $\left(-80^{\circ} \mathrm{C}\right)$ nucleic acid extracts, MAV2-F/Yan-R primers and processed as previously described.

Nucleotide sequences were obtained on both strands from PCR-generated Shu-F/Yan-R fragments for 24 isolates: sequences were also obtained on one strand from MAV2-F/Yan$\mathrm{R}$-generated fragments for 14 of the 16 additional isolates in Table 1. All sequences were first examined and compared with each other using the Sequencher program (Gene Codes Corp., Ann Arbor, MI, USA), followed by a quick identity assessment with other viruses using BLAST (basic local alignment search tool), nucleotide-nucleotide (blastn) program in NCBI (National Center for Biotechnology Information).

\section{Genetic analysis}

Sequence alignments were completed by the Clustal_X program [27]. Neighbor-joining trees for the CP (Fig. 2a) and ORF 4 (Fig. 2b) were based on distances of net amino acid sequence differences and constructed with PAUP (Phylogenetic Analysis Using Parsimony) [26]. Distribution of amino acid sequence similarities on the CP among selected BYDV isolates that represented each clade from the CP phylogenetic tree (Fig. 2a) were visualized with a Hypercard computer program [9] using a sliding window of 10 amino acids (Fig. 3). Identities for CP nucleotide sequences and amino acid sequences for the $\mathrm{CP}$ and $\mathrm{ORF} 4$

Table 2. Percent sequence identities within (on the diagonal in bold) and between (below the diagonal) BYDV phylogenetic clusters, exclusive of PAV CN and Saldus1. The first number is percent nucleotide identity of the coat protein gene, and the second and third numbers are percent amino acid identities of the coat protein and ORF 4, respectively. As only one SGV sequence was used as the outgroup, within group diversity values are not applicable (na) for SGV

\begin{tabular}{llllll}
\hline $\begin{array}{l}\text { Viruses* } \\
\text { no. of isolates }\end{array}$ & AK MAV-like & MAV & PAV & PAS & SGV \\
\hline
\end{tabular}

\begin{tabular}{|c|c|c|c|c|c|}
\hline AK MAV-like* (27) & 98.397 .299 .4 & & & & \\
\hline $\mathrm{MAV}^{*}(6)$ & $\underline{83.2} \underline{77.3} \underline{80.2}$ & $\underline{98.5} \underline{97.9} \underline{98.3}$ & & & \\
\hline $\mathrm{PAV}^{*}(7)$ & 74.464 .170 .1 & 77.172 .470 .5 & $95.896 .3 \underline{90.4}$ & & \\
\hline $\mathrm{PAS}^{*}(4)$ & $\overline{74.2} \underline{64.9} \underline{73.5}$ & $\overline{77.3} \underline{71.1} \underline{73.0}$ & $\underline{88.3} \underline{84.8} \underline{87.7}$ & $96.892 .9 \underline{97.6}$ & \\
\hline $\mathrm{SGV}^{*}(1)$ & $69.0 \underline{57.9} \underline{64.4}$ & $67.7 \underline{58.8} \underline{59.0}$ & $67.159 .9 \underline{59.7}$ & $67.957 .8 \underline{57.5}$ & na na na \\
\hline
\end{tabular}


(Table 2) were determined among 27 Alaskan isolates collected in 2003 (23) and 2004 (4), and BYDV isolates from other geographical regions using the MEGA3.1 computer program [14].

\section{Results}

\section{ELISA}

None of the leaf sap preparations derived from 41 oat plants reacted to the specific antibodies from BYDV-MAV, BYDV-PAV, BYDV-SGV, or CYDV-RPV in ELISA tests. Extracts from all plants and controls were assayed at least three times for confirmation.

\section{Sequences of PCR products}

The "universal luteovirus" and "sobemovirus-like polymerase" primer sets failed to generate amplified DNA fragments from any of the 41 oat plants from field 5, with one exception, using the former primer set (Fig. 1, Table 1). However, about two years later, successful RT-PCR detection of BYD using the same nucleic acid extracts with Yan-R primer for cDNA synthesis, and Shu-F/Yan-R primers in PCR, resulted in amplified DNA fragments of the predicted size $\sim 830$ bp (Fig. 1, Table 1). In fact, nearly $68 \%$ (27 out of 41 ) of the collected plants were tentatively identified to have been infected with at least one of the following: BYDVMAV, BYDV-PAS, BYDV-PAV, or BYDV-SGV; sequences were obtained from 24 isolates as indicated with corresponding accession numbers. Subsequently, sixteen of these isolates were tentatively identified as BYDV-MAV-like from

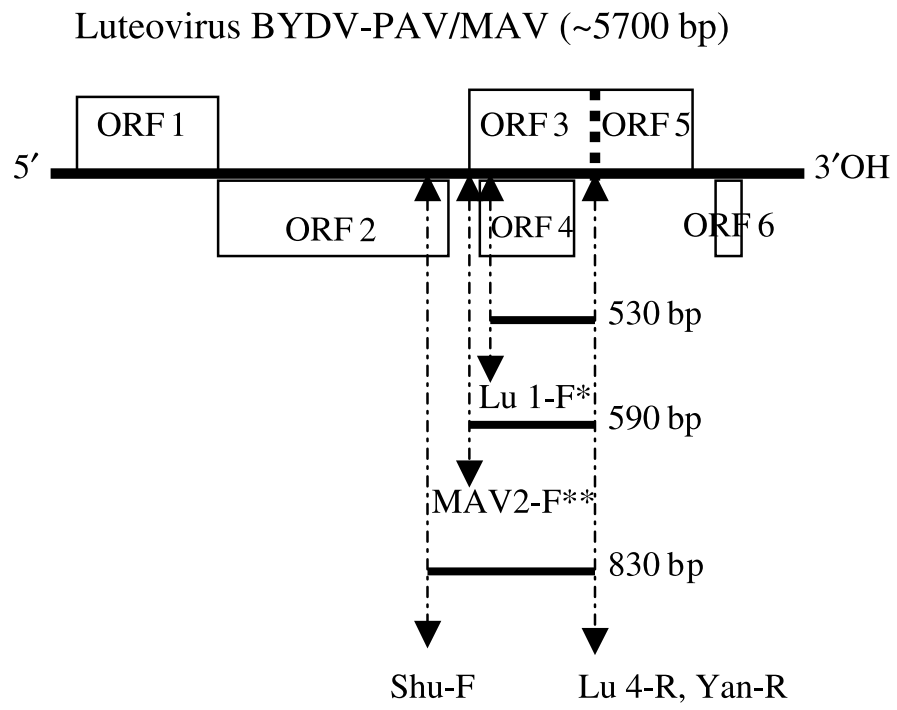

Fig. 1. Genomic map of members of the genus Luteovirus, depicting sequence placement of primers that successfully generated PCR fragments of predicted sizes; sequence mismatch and failure to produce PCR fragments for *MAV-like or ** PAV-like genomes 
the detection of 590-bp fragments generated with MAV2-F/Yan-R by PCR, and 14 of these were successfully sequenced; no PCR fragments occurred from the other isolates with MAV2-F/Yan-R, PAV-F/Yan-R, or SGV-R/Shu-F primers sets. The other sites within several kilometers of the original "MAV-site" that were

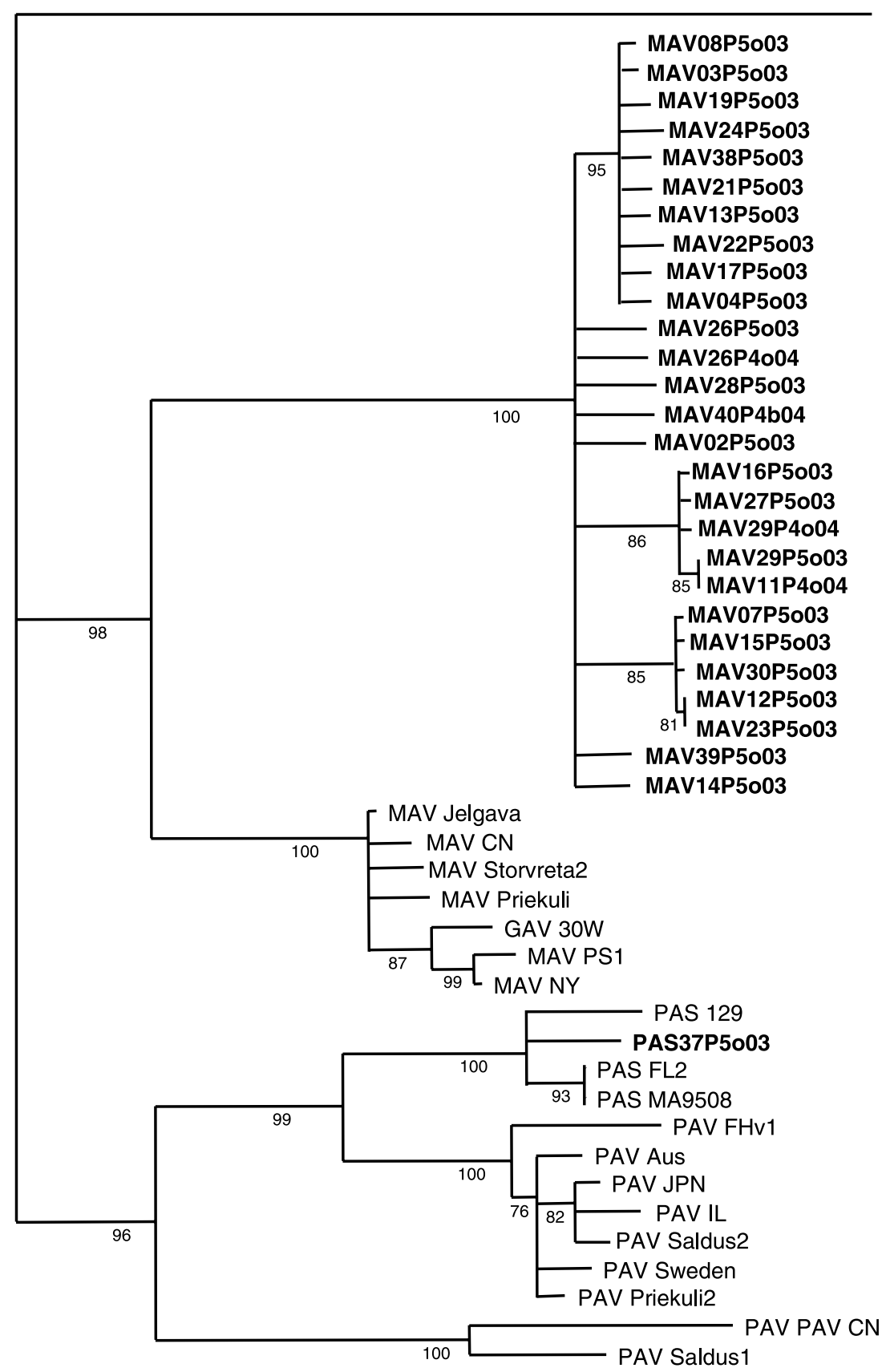

Fig. 2 (continued) 
assayed in 2003-04 only contained MAV-like isolates from 2004, including one isolate (MAV40P4b04, accession no. DQ680140) from 13 barley plants and three isolates (MAV11P4o04, accession no. DQ680137; MAV26P4o04, accession no. DQ680138; MAV29P4o04, accession no. DQ680139) from 33 oat plants. The four 2004 isolates contained sequences similar to each other and to the AK BYDVMAV-like isolates from 2003 (Fig. 2a, b, Table 2).

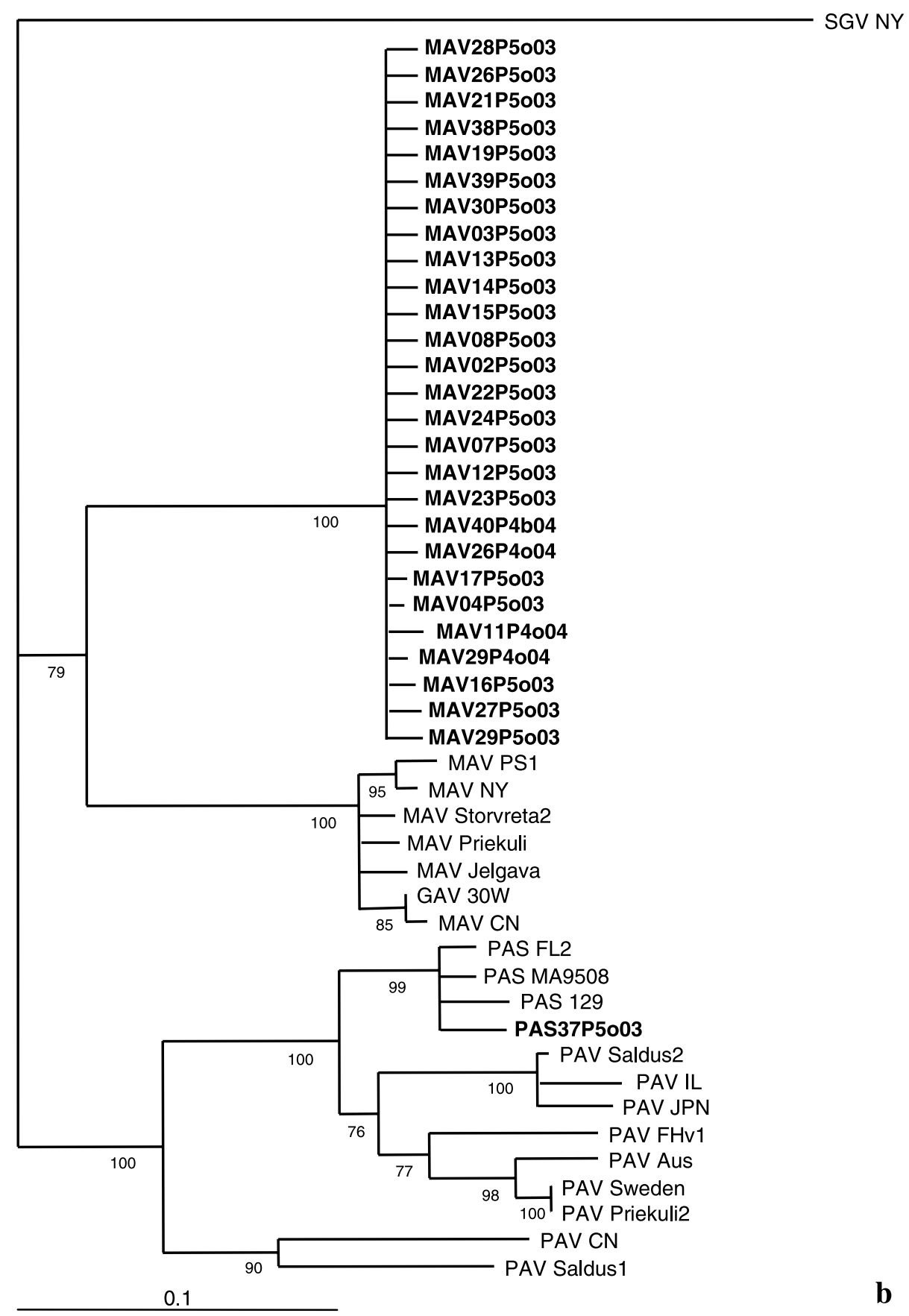


All AK isolates except one (PAS37P5o03) aligned together with Sequencher with limited mismatches and were most similar to BYDV-MAVs sequences when analyzed with blastn. Two clones (accession nos. DQ683252, DQ792506) derived from plant no. 37 (isolate PAS37P5o03) using Lu 1/Lu 4 and Shu-F/Yan-R primers, respectively, contained nearly identical 502-nt (one mismatch) between the Lu1 and Lu 4 sites. The larger PAS37P5o03 clone (DQ792506) contained nucleotide sequences $(49-163,164-757,206-667 \mathrm{nt})$ that were 96,98 , and $98 \%$ identical to the intergenic region, ORF 3 (lacking 3'-terminus of CP gene), and ORF 4, respectively, with the New York BYDV-PAS (accession no. AF218798, 27442857, 2858-3452, 2901-3362 nt, respectively).

Phylogenetically, all 27 AK BYDV-MAV-like isolates clustered in one clade when analyzing amino acid sequences among other BYDV species in the CP (Fig. 2a) and ORF 4 (Fig. 2b). These isolates were 98.3 and 97.2\% identical in nucleotide (nt) and amino acid (aa) sequences of the $\mathrm{CP}$ gene, respectively, and more conserved in the ORF 4 protein with a 99.4\% identity (Table 2). When compared to other BYDV isolates, the AK isolates were most similar to BYDVMAV, with sequence percent identities of 83.2, 77.3, and 80.2 in the CP nt, CP aa, and ORF 4 aa, respectively (Table 2). The putative movement protein, ORF 4, was more conserved relative to the $\mathrm{CP}$, with a difference of $+2.2,+0.4$, and $+4.7 \%$ in the AK MAV-like, MAV, and PAS clade, and less conserved in the PAV clade at $-5.9 \%$ (Table 2).

The distribution of amino acid differences along the CP was obvious when comparing sequences of an AK MAV-like isolate (MAV07P5o03) with representative members from the distinct clades (Fig. 3). Notably, differences between the three AK isolates and the other BYDV isolates occur on the $5^{\prime}$-termini. The AK isolates are most similar to MAV PSI and GAV 30W near the $3^{\prime}$-termini.

The AK BYDV-MAV-like isolates contained a 113-nt intergenic region between the polymerase (ORF 2$)$ and $\mathrm{CP}(\mathrm{ORF} 3)$ genes that were at least $95 \%$ similar

Fig. 2. Phylogenetic trees depicting relationships among 27 Barley yellow dwarf virus (BYDV)-MAV-like isolates (accession numbers: DQ680114-DQ680140) and one PAS-like isolate (accession no. DQ792506) from Alaska and other selected BYDV-MAV, -GAV, -PAS, -PAV isolates comparing amino acid sequences of the CP gene, ORF 3 (Fig. 2a), or the putative movement gene, ORF 4 (Fig. 2b). The Alaska isolates are in bold as: MAV or PAS, $\mathbf{x x}$ (sample number), $\mathbf{P}$ (Palmer = location), $\mathbf{o}$ or $\mathbf{b}$ (oat or barley = plant host), $\mathbf{0 3}$ or $\mathbf{0 4}$ (year collected). The associated country and accession number are included with the other isolates: GAV 30w (China, AY610953), MAV CN (China, AF338909), MAV Jelgava (Latvia, AJ563519), MAV NY (USA, X53174), MAV PSl (USA, D11028), MAV Priekuli (Latvia, AJ563417), MAV Storvreta2 (Sweden, AJ563417), PAS 129 (USA, AF218798), PAS FL2 (France, AJ223586), PAS MA9508 (Morocco, AJ007921), PAV Aus (Australia, M21347), PAV CN (China, AF192967), PAV FHv1 (France, AJ007491), PAV IL (USA, AF235167), PAV JPN (Japan, D85783), PAV Priekuli2 (Latvia, AJ563414), PAV Saldus1 (Latvia, AJ563410), PAV Saldus2 (Latvia, AJ563411), PAV Sweden (Sweden, AJ563415) and SGV NY (USA, U06865). The scale bar (0.1) means a distance of $10 \%$ with both trees drawn to the same scale. Bootstrap values are percent results from 1000 bootstrap replications 


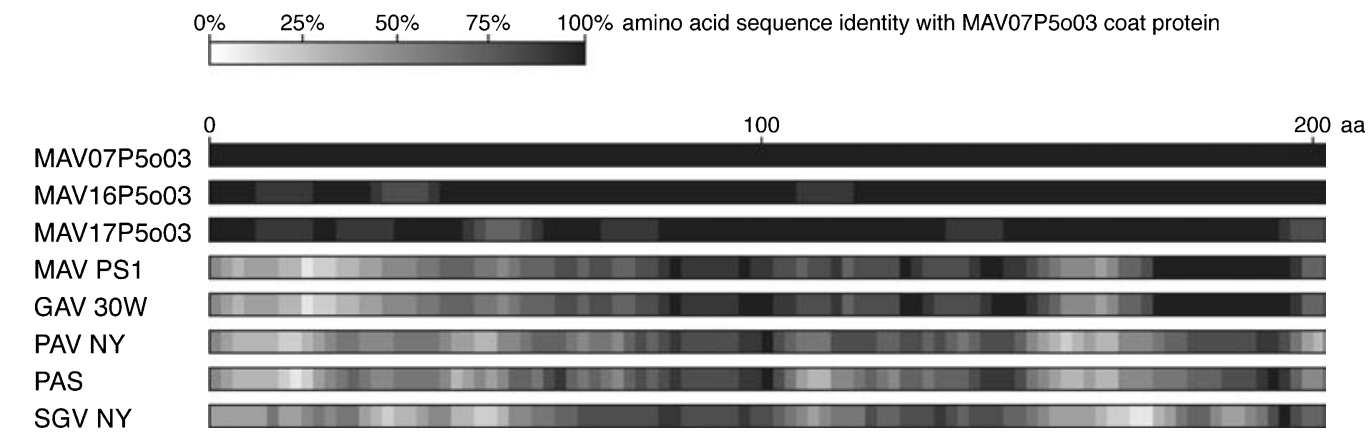

Fig. 3. Coat protein amino acid sequence comparisons and distributions of an Alaska BYDVMAV-like isolate (MAV07P5o03, accession no. DQ680114) with two AK MAV-like isolates (MAV16P5o03, DQ680122; MAV17P5o03, DQ680132), and five other BYDV isolates (accessions nos. in parenthesis): MAV PSI (X17260), GAV30W (AY610953), PAV NY (X56050), PAS (AF218798) and SGV NY (U06865)

to each other, and, interestingly, more similar to BYDV-PAS-129 (85.9-87.0\%) and BYDV-PAV NY (82.8-83.8\%) than to BYDV-MAV-PSI (81.3-82.3\%).

\section{Discussion}

Failure to initially detect B/CYDVs from field plants with classical BYD symptoms by two very specific and sensitive detection methods presented a dilemma that is occasionally encountered in field diagnostics. We had tentatively concluded that the sampled oats plants did not have BYD disease, but rather were infected by another pathogen such as aster yellows phytoplasma, or had a nutrient deficiency that caused similar symptoms [3]. Similar detection problems involving large numbers of symptomatic plants did not occur on other sites in the Matanuska Valley, where infections by BYDV-PAV and CYDV-RPV were readily confirmed by ELISA and RT-PCR [23]. Bisnieks [1] reported successful detection and amplification of the CP gene for BYDV-PAV and CYDV-RPV, and not isolates of BYDV-MAV, using immunocapture RT-PCR with the appropriate antiserum and the universal luteovirus primers. They subsequently incorporated a specific primer set for successful BYDV-MAV amplification and analysis. As previously stated, Malmstrom and Shu [17] developed a multiplexed RT-PCR strategy for detection and separation of B/CYDV serotypes using multiple primers sets. They concluded that their MAV2-F (5'-AATAACCGCCAGGAGAAATGG-3') and Yan-R primer pair were specific for BYDV-MAV and not BYDV-PAV and BYDV-SGV. Upon examination of the nucleotide sequences in the AK BYDV-MAV-like isolates and available sequences for BYDV-MAV from data banks, the suitability and application of the various primers designed by different researchers for detection became evident. Firstly, the universal Lu 1 primer, 5'-CCAGTGGTTRT GGTC-3', was not useable for detection for any BYDV-MAV [1, 15, 17], including the AK BYDV-MAV-like isolates, since there was no sequence counterpart in the coat protein region, with a specific mismatch in the equivalent region, 


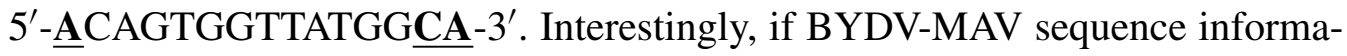
tion had been available for the original design of the universal luteovirus primers [25], Lu 1 probably would not have been formulated. Ironically, the $\mathrm{Lu} 1 / \mathrm{Lu} 4$ primers continue to be exceedingly useful and dependable for sensitive detection of most members of the family Luteoviridae, and for finding new viruses such as sweet potato leaf speckling virus [10], and more recently, BYDV-OYV (oat yellowing virus) $=$ PAV-Sal1 [1]

Secondly, the primer set designed by Bisnieks [1] that specifically targets BYDV-MAVs would not be useful in detecting the Alaska isolates since the M3 forward primer, 5'-ATG AAT TCA GTA GGC CGT AG-3', contained two nucleotide mismatches (underlined) at critical locations on the $3^{\prime}$-terminus for

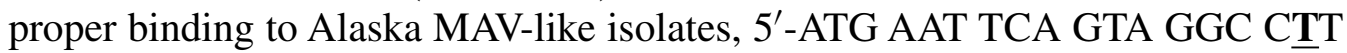
A-ㅡㄴ' (i.e. MAV07P5o03, accession no. DQ680114, 194-213 nt). Finally, the primer set instrumental in diagnosing the problematic oat plants in Alaska, Shu-F/Yan-R (Table 1) was designed to detect BYDVs that share features with carmoviruses in their RNA-dependent RNA polymerase (ORF 2) such as BYDVMAV, -PAV, and -SGV. The sequences obtained from the resulting PCR fragments were obviously most similar to BYDV-MAV and distantly related to BYDVPAV. This is in contrast to the negative results with the primers, Pol $1 / \mathrm{Lu} \mathrm{4,}$ which targeted BYDV-causing viruses with a sobemovirus-like polymerase such as BYDV-RMV and BYDV-RPV. Partial success with the MAV specific primer, MAV2-F (5'-AAT AAC CGC AGGAGAAAT GG-3'), provided the correctly sized amplified fragment on 16 of the 27 isolates previously amplified with Shu-F/Yan$\mathrm{R}$ primers and suggested that 16 plants were in fact infected with BYDV-MAV. However, since the Alaska isolates had little sequence similarity with the forward primer's 5'-half (underlined, bold), 5' -AGA AAG AGG AAG AGA AAT GG-3' (i.e. MAV07P5o03, accession no. DQ680114, 221-237 nt), the species identity as BYDV-MAV was questionable. Conclusions as to species identity based on size of PCR products without sequence analysis need to be scrutinized, especially in surveys involving a large number of isolates where it may not be practical to obtain sequences for all "positive" fragments.

Essentially, amino acid regions along the $\mathrm{CP}$ of $\mathrm{B} / \mathrm{CYDV}$ s determine serological affinities with defining epitopes on the virion surface [21,23]. Unlike most plant viruses, the coat protein gene is the most conserved among the luteoviruses and explains frequent cross reactions between them [5]. The antisera used in this study specifically distinguished BYDV-MAV, -PAV, and CYDV-RPV using polyclonal antibodies for capture and monoclonal antibodies for detection, avoiding cross reactivity. Obviously, the Alaska BYDV-MAV-like isolates did not share epitopes responsible for binding to the monoclonal antibodies that were utilized in the ELISA. Even though Alaska isolates appeared to be most similar to BYDVMAVs and BYDV-GAV, pronounced differences in amino acid segments in the $\mathrm{CP}$, especially in the amino terminus (Fig. 3) most likely accounted for the lack of serological detection.

Based on prior field surveys in Alaska, incidence of BYDV-PAS-infected plants was overwhelmingly most prevalent in both oats and barley (unpublished, 
N. L. Robertson and R. French). It is curious that out of 41 plants from the oat field, only one plant was infected with BYDV-PAS, 26 plants with BYDVMAV-like isolates, and no plants contained multiple infections. Why a susceptible plant species is infected by a particular C/BYDV is complex, involving intimate relationships between the plant host, specific aphid vector, infecting virus, and influential environmental parameters. The phenomenon of cross protection in plants have been documented for BYD, whereby multiple infections may occur with unrelated viruses such as BYDV-PAV and CYDV-RPV, or are greatly reduced with closely related viruses such as BYDV-MAV and BYDV-PAV [29]. Multiple infections of viruses have never been documented among viruses with similar polymerase genes [20], and the correlation with cross protection, or controlling mechanism(s) are not understood [12]. If, in fact, AK BYDV-MAV-like isolates were closely related to Alaska BYDV-PAS, then, most likely, cross protection would have occurred between the two viruses, and the plant likely was infected with the first delivered virus. Other factors that may influence the incidence of infection, but are not known for Alaska's B/CYDVs, are the similarities and differences of native aphid vectors and alternative plant hosts.

The phylogenetic relationship depicted between the AK BYDV-MAV-like isolates and BYDV-MAV, -PAS, and -PAV isolates is suggestive that the AK isolates should be placed in the genus Luteovirus (Fig. 2a, b). The AK BYDVMAV-like isolates also have a short intergenic region between the polymerase and cp genes $(113 \mathrm{nt})$ that is comparable with the luteovirus members, and unlike the longer intergenic region ( $200 \mathrm{nt}$ ) common to members of the genus Polerovirus $[4,20]$. Another unassigned member, BYDV-GAV, is prevalent in China and serologically related to BYDV-MAV and contains similar sequences in the ORFs, except for ORF 5 and $6[13,28]$. Based on the sequence information available for the Alaska BYDV-MAV-like isolates, we concluded that the similarly related BYDV-GAV and BYDV-MAV have the greatest affinity to the AK isolates when compared to other viruses in the data banks. However, inclusion of these AK isolates with a particular luteovirus species including BYDV-GAV and BYDVMAV is not allowed since they share less than $90 \%$ amino acid identity in the CP and ORF 4 and therefore do not meet the criteria for placement into an existing species [4]. The full-length genomic sequence of the Alaska BYDV-MAV-like isolates will provide additional sequence data for other important genes such as the polymerase gene and the overall genomic organization required for their classification and taxonomic placement with other viruses [22]. It could also lead into speculative ancestral recombination events such as between PAS and MAV in the generation of the novel AK BYDV-MAV-like isolates. We propose to name the described Alaskan BYDV-MAV-like isolates after their apparent host preference and associated red colour, BYDV-ORV (ORV for oat red-leaf virus).

\section{Acknowledgements}

We thank Kathryn Brown for laboratory assistance and Lori Winton for review of manuscript. 


\section{References}

1. Bisnieks M, Kvarnhedon A, Sigvald R, Valkonen JPT (2004) Molecular diversity of the coat-protein-encoding region of barley yellow dwarf virus-PAV and barley yellow dwarf virus-MAV from Latvia and Sweden. Arch Virol 149: 843-853

2. Chay CA, Smith DM, Vaughan R, Gray SM (1996) Diversity among isolates within PAV serotype of barley yellow dwarf virus. Phytopathology 86: 370-377

3. D'Arcy CJ (1995) Symptomology and host range of barley yellow dwarf. In: D'Arcy CJ, Burnett PA (eds) Barley yellow dwarf: 40 years of progress. APS Press, St. Paul, MN, pp 9-28

4. D'Arcy CJ, Domier LL, Mayo MA (2000) Family Luteoviridae. In: van Regenmortel HVM, Fauquet CM, Bishop DHL, Carstens EB, Estes MK, Lemon SM, Maniloff J, Mayo MA, McGeoch DJ, Pringle CR, Wickner RB (eds) Virus Taxonomy: Seventh Report of the International Committee on the Taxonomy of Viruses. Academic Press, San Diego, CA, pp 775-784

5. D'Arcy CJ, Torrance L, Martin RR (1989) Discrimination among luteoviruses and their strains by monoclonal antibodies and identification of common epitopes. Phytopathology 79: 869-873

6. Davis LT, Guy PL (2001) Introduced plant viruses and the invasion of a native grass flora. Biolo Invasions 3: 89-95

7. Foster GN, Blake S, Tones SJ, Barker I, Harrington R (2004) Occurrence of barley yellow dwarf virus in autumn-sown cereal crops in the United Kingdom in relation to field characteristics. Pest Manag Sci 60: 113-125 (online: 2004) DOI: 10.1002/ps.796

8. French R (1995) Barley yellow dwarf: diagnostic procedures and reagents. In: D'Arcy CJ, Burnett PA (eds) Barley yellow dwarf: 40 years of progress. APS Press, St. Paul, MN, pp 293-305

9. Fröhlich K-U (1994) Sequence similarity presenter: a tool for the graphic display of similarities of long sequences for use in presentations. Comput Appl Biosci 10: 179-183

10. Fuentes S, Mayo MA, Jolly CA, Nakano M, Querci M, Salazar LF (1996) A novel luteovirus from sweet potato, sweet potato leaf speckling virus. Ann Appl Biol 128: 491-504

11. Geske SM, French R, Robertson NL, Carroll TW (1996) Purification and coat protein gene sequence of a Montana RMV-like isolate of barley yellow dwarf virus. Arch Virol 141: 541-556

12. Haber S (1995) Interactions of barley yellow dwarf viruses: cross-protection and interactions with other pathogens and with abiotic factors. In: D'Arcy CJ, Burnett PA (eds) Barley yellow dwarf: 40 years of progress. APS Press, St. Paul, MN, pp 145-161

13. Jin Z, Wang X, Chang S, Zhou G (2004) The complete nucleotide sequence and its organization of the genome of barley yellow dwarf virus-GAV. Sci China C Life Sci 47: $175-182$

14. Kumar S, Tamura K, Nei M (2004) MEGA3: Integrated software for molecular evolutionary genetics analysis and sequence alignment. Brief Bioinformatics 5: 150-163

15. Lapierre H (2004) Family Luteoviridae. In: Lapierre H, Signoret P-A (eds) Viruses and Virus Diseases of Poaceae (Graminae). INRA Editions, Paris, France, pp 366-370

16. Lister RM, Ranieri R (1995) Distribution and economic importance of barley yellow dwarf virus. In: D'Arcy CJ, Burnett PA (eds) Barley yellow dwarf: 40 years of progress. APS Press, St. Paul, MN, pp 29-53

17. Malmstrom CM, Shu R (2004) Multiplexed RT-PCR for streamlined detection and separation of barley and cereal yellow dwarf viruses. J Virol Methods 120: 69-78 
18. Martin RR, D'Arcy JD (1995) Taxonomy of barley yellow dwarf viruses. In: D'Arcy CJ, Burnett PA (eds) Barley yellow dwarf: 40 years of progress. APS Press, St. Paul, MN, pp 203-214

19. Mayo MA (2002) ICTV at the Paris ICV: Results of the Plenary Session and the binomial Ballot. Arch Virol 147: 2254-2260

20. Mayo MA, Miller WA (1999) The structure and expression of luteovirus genomes. In: Smith SG, Baker H (eds) The Luteoviridae. CABI Publishing, Wallingford, UK, pp 23-42

21. Mayo MA, Ziegler-Graff V (1996) Molecular biology of luteoviruses. Adv Virus Res 46: 413-460

22. Miller WA, Liu S, Beckett R (2002) Barley yellow dwarf virus: Luteoviridae or Tombusviridae? Mol Plant Pathol 3: 177-183

23. Rizzo TM, Gray SM (1992) Localization of a surface domain of the capsid protein of barley yellow dwarf virus. Virology 186: 300-302

24. Robertson NL (2003) Luteovirus and polerovirus found in small grains for the first time in the Matanuska-Susitna region of Alaska. Plant Dis 87: 446

25. Robertson NL, French R, Gray SM (1991) Use of group specific primers and the polymerase chain reaction for the detection and identification of luteoviruses. J Gen Virol 72: 1473-1477

26. Swofford DL (2002) PAUP*. Phylogenetic Analysis Using Parsimony (*and other Methods), Version 4.0b8a. Sinauer, Sunderland, MA

27. Thompson JD, Gibson TJ, Plewniak F, Jeanmougin F, Higgins DG (1997) The Clustal_X windows interface: flexible strategies for multiple sequence alignment aided by quality analysis tools. Nucleic Acids Res 25: 4876-4882

28. Wang X, Chang S, Jin Z, Li L, Zhou G (2001) Nucleotide sequences of the coat protein and readthrough protein genes of the Chinese GAV isolate of barley yellow dwarf virus. Acta Virol 45: 249-252

29. Wen RM, Lister RM, Fattouh FA (1991) Cross-protection among strains of barley yellow dwarf virus. J Gen Virol 72: 791-799

Author's address: Nancy L. Robertson, USDA, ARS, Arctic Germplasm Introduction and Research, 533 E. Fireweed Ave. Palmer, Alaska 99645, U.S.A.; e-mail: pfnlr@uaa.alaska.edu 